\title{
Purification and characterization of rat adipose tissue lipoprotein lipase
}

\author{
Susan M. PARKIN, Brian K. SPEAKE and Donald S. ROBINSON \\ Department of Biochemistry, University of Leeds, Leeds LS2 9JT, U.K.
}

(Received 1 June 1982/Accepted 17 August 1982)

\begin{abstract}
Lipoprotein lipase (EC 3.1.1.34) extracted from adipose tissue of glucose-fed rats with $5 \mathrm{~mm}$-sodium barbital, $\mathrm{pH} 7.5$, containing $20 \%(\mathrm{v} / \mathrm{v})$ glycerol and $0.1 \%(\mathrm{v} / \mathrm{v})$ Triton $\mathrm{X}-100$, was partially purified by affinity chromatography on heparin linked to Sepharose 4B. Sodium dodecyl sulphate/polyacrylamide-gel electrophoresis of the partially purified enzyme preparation revealed the presence of two major Coomassiestaining bands (mol.wts. 62000 and 56000) as well as a number of minor bands. Treatment of partially purified enzyme with $\left[1,3-{ }^{3} \mathrm{H}\right] \mathrm{di}$-isopropyl fluorophosphate resulted in the incorporation of radiolabel into the band of mol.wt. 56000, but not into the band of mol.wt. 62000 . Both the amount of the 56000-mol.wt. polypeptide and the incorporation of $\left[1,3-{ }^{3} \mathrm{H}\right]$ di-isopropyl fluorophosphate into this band were greatly reduced in the enzyme preparations isolated from adipose tissue of $48 \mathrm{~h}$-starved rats, whereas the amount of the 62000 -mol.wt. polypeptide was unaffected by starvation. Purification of lipoprotein lipase from adipose tissue of glucose-fed rats was also carried out using affinity chromatography on Sepharose 4B linked to heparin with low affinity for antithrombin-III. This procedure resulted in the presence of a single band of mol.wt. 56000 on sodium dodecyl sulphate/polyacrylamide-gel electrophoresis. These results suggest that the polypeptide of mol.wt. 56000 corresponds to the subunit of lipoprotein lipase, whereas the 62000 -mol.wt. polypeptide probably represents antithrombin-III.
\end{abstract}

Lipoprotein lipase (EC 3.1.1.34) catalyses the hydrolysis of plasma chylomicron and very-lowdensity lipoprotein triacylglycerols and thereby facilitates the removal of triacylglycerol fatty acids from the circulation. The enzyme is thought to be synthesized in a number of different extrahepatic tissues and to be secreted by the cells thereof for transport to a site at the luminal surfaces of the capillary endothelial cells where it exerts its activity (Robinson, 1970). Tissue-specific changes in lipoprotein lipase activity occur with the result that triacylglycerol fatty acids are also directed to different tissues according to their metabolic requirements. For example, the lipoprotein lipase activity of rat adipose tissue decreases with starvation, whereas that of the heart increases, and these changes are accompanied by corresponding changes in triacylglycerol fatty acid uptake by these tissues (Robinson, 1970; Borensztajn et al., 1970; Cryer et al., 1976). Again, the lipoprotein lipase activity of the mammary gland rises at parturition, as does the capacity of the gland to take up triacylglycerol fatty

Abbreviations used: DFP, di-isopropyl fluorophosphate; SDS, sodium dodecyl sulphate. acids from the blood (Robinson, 1970). On the other hand, the activity of the enzyme in adipose tissue declines during pregnancy and lactation (Otway \& Robinson, 1968; Hamosh et al., 1970).

Such changes in the activity of the enzyme are believed to be hormonally determined and in recent years the control of the activity of the enzyme in rat adipose tissue by hormones has been a particular interest of this laboratory (Ashby et al., 1978b; Ashby \& Robinson, 1980; Parkin et al., 1980). However, whereas the enzyme has been purified from human, porcine and avian adipose tissue, as well as from heart, milk and post-heparin plasma in a number of species (Nilsson-Ehle et al., 1980), there is little information on the molecular properties of the enzyme from rat adipose tissue (Greten \& Walter, 1973; Etienne et al., 1976). In this paper we report the partial purification of the enzyme from this source, using the techniques of chromatography on heparin-Sepharose and concanavalin ASepharose that have been widely applied elsewhere, and provide evidence that the subunit of the enzyme, after separation by SDS/polyacrylamide-gel electrophoresis, has an apparent molecular weight of about 56000 . 


\section{Materials and methods}

\section{Materials}

Heparin solution ( 1000 units $/ \mathrm{ml}$ ) used in the assay of lipoprotein lipase was supplied by Evans Medical, Speke, Liverpool, U.K. Sodium heparin (grade II) from pig intestinal mucosa, used for preparing heparin-Sepharose 4B, and jack-bean meal, used in the preparation of concanavalin $A$, were purchased from Sigma Chemical Co., Kingston-upon-Thames, Surrey, U.K. Heparin with a low affinity for antithrombin, which was coupled to Sepharose 4B in some experiments, was a gift from Dr. E. Holmer, Kabi AB Co., Stockholm, Sweden:

DFP, bovine serum albumin, catalase, methyl $\alpha$-D-glucoside, methyl $\alpha$-D-mannoside and acetonitrile were purchased from Sigma Chemical Co., $\left[1,3-{ }^{3} \mathrm{H}\right]$ DFP (sp. radioactivity $6.5 \mathrm{Ci} / \mathrm{mmol}$ ) was obtained from Amersham International, Amersham, Bucks., U.K. Sepharose 4B was purchased from Pharmacia, Uppsala, Sweden, and $\mathrm{CNBr}$ was obtained from Aldrich Chemical Co., Gillingham, Dorset, U.K. Other materials were as specified by Parkin et al. (1980) or were supplied by BDH Chemicals, Poole, Dorset, U.K.

\section{Animals}

Specific-pathogen-free male rats of the Wistar strain and of body weight ranging from 250 to $500 \mathrm{~g}$ were used (A. Tuck \& Son., Rayleigh, Essex, U.K.). They were maintained on Oxoid pasteurized diet 41B (Herbert Styles, Bewdley, Worcs., U.K.). Rats were killed between $09: 00 \mathrm{~h}$ and 10:00 h in either the glucose-fed state or after starvation for $48 \mathrm{~h}$, by stunning, followed by neck fracture. For 'glucosefed' rats, the drinking water was replaced by a glucose solution $(10 \%, \mathrm{w} / \mathrm{v}) 18 \mathrm{~h}$ before killing and the animals still had access to their maintenance diet. In experiments where tissues from glucose-fed and $48 \mathrm{~h}$-starved rats were compared, equal numbers of rats from the same batch were always used.

\section{Acetone/diethyl ether-dried preparations of adipose tissue}

These were made by techniques similar to those previously described (Ashby et al., 1978a) either from epididymal fat-bodies that had been stored in liquid $\mathrm{N}_{2}$ at $-70^{\circ} \mathrm{C}$ for between 1 and 10 weeks or from fat-bodies immediately after removal from the animals.

The fat-bodies were blended in water at $4^{\circ} \mathrm{C}$ ( $2 \mathrm{ml} / \mathrm{g}$ wet wt. of tissue) and the homogenate was poured into acetone at $-18^{\circ} \mathrm{C}(35 \mathrm{ml} / \mathrm{g}$ wet wt. of tissue). The precipitate was collected on filter paper and washed with acetone $(25 \mathrm{ml} / \mathrm{g}$ wet wt. of tissue) and then with the same volume of diethyl ether at $20^{\circ} \mathrm{C}$. Finally it was dried under vacuum and stored at $-70^{\circ} \mathrm{C}$ for up to 6 weeks. Twenty rats gave about
$100 \mathrm{~g}$ tissue, which yielded between 1 and $1.5 \mathrm{~g}$ of defatted dried residue.

\section{Extraction and assay of lipoprotein lipase}

The acetone/diethyl ether-dried preparations were finely chopped and soaked for $30 \mathrm{~min}$ at $4{ }^{\circ} \mathrm{C}$ in the buffer solution described $(1 \mathrm{~g} / 35 \mathrm{ml}$ of buffer). They were homogenized and then centrifuged for $30 \mathrm{~min}$ at $60000 \mathrm{~g}$ at $4^{\circ} \mathrm{C}$. Lipoprotein lipase was assayed in the homogenates, in the supernatants after centrifugation (referred to as extracts in the text) and in fractions purified therefrom, by measuring the release of fatty acids from an activated triacylglycerol substrate at $30^{\circ} \mathrm{C}$. Assay was by the method of Riley \& Robinson (1974) as modified by Parkin et al. (1980). Sample volumes of up to $150 \mu 1$ were used in a final assay volume of $1 \mathrm{ml}$. In some of the assays, heparin was present $(0.5 \mathrm{unit} / \mathrm{ml})$. One unit of enzyme activity is defined as the amount of enzyme releasing $1 \mu \mathrm{mol}$ of fatty $\mathrm{acid} / \mathrm{h}$ in the assay.

\section{Heparin-Sepharose chromatography}

Heparin-Sepharose was routinely prepared by the method of Miller-Anderson et al. (1974) using $100 \mathrm{mg}$ of $\mathrm{CNBr}$ and $10 \mathrm{mg}$ of heparin $/ \mathrm{ml}$ of Sepharose 4B. Because only a small amount $(70 \mathrm{mg})$ of heparin with a low affinity for antithrombin was available, the amounts used in this case were $75 \mathrm{mg}$ of $\mathrm{CNBr}$ and $4 \mathrm{mg}$ of heparin/ml of Sepharose $4 \mathrm{~B}$. The heparin-Sepharose columns were equilibrated in 5 mM-sodium barbital, pH 7.5, containing $20 \%$ (v/v) glycerol. Extracts of lipoprotein lipase were applied and the columns were washed and eluted as described in the text. All chromatography was performed at $4^{\circ} \mathrm{C}$.

\section{Concanavalin A-Sepharose chromatography}

Concanavalin A was prepared from jack-bean meal by the method of Agrawal \& Goldstein (1967). Sepharose 4B was activated by the method of Porath et al. (1973), except that acetonitrile was used as the solvent for the $\mathrm{CNBr}(25 \mathrm{mg} / \mathrm{ml}$ of gel). Concanavalin A $(10 \mathrm{mg} / \mathrm{ml}$ gel) was coupled to the activated Sepharose 4B in $0.2 \mathrm{M}-\mathrm{NaHCO}_{3}, \mathrm{pH} 9.0$, containing $0.5 \mathrm{M}-\mathrm{NaCl}$ at $20^{\circ} \mathrm{C}$ for $16-18 \mathrm{~h}$. The efficiency of coupling was 50-70\%. After thorough washing, a column of concanavalin A-Sepharose was equilibrated in 5 mM-sodium barbital, $\mathrm{pH} 7.5$, containing $20 \%(\mathrm{v} / \mathrm{v})$ glycerol, $1 \mathrm{M}-\mathrm{NaCl}, 5 \mathrm{mM}-$ $\mathrm{CaCl}_{2}$ and $5 \mathrm{mM}-\mathrm{MnCl}_{2}$. Heparin-Sepharosepurified preparations of lipoprotein lipase were applied to the concanavalin $\mathrm{A}$-Sepharose and the column was washed with 5-10vol. of the equilibration buffer. Lipoprotein lipase was eluted with this buffer containing $0.6 \mathrm{M}$-methyl $\alpha$-D-mannoside and $0.6 \mathrm{M}$-methyl $\alpha$-D-glucoside. All operations were carried out at $4^{\circ} \mathrm{C}$. 


\section{SDS/polyacrylamide-gel electrophoresis}

Protein fractions from chromatography on heparin-Sepharose and concanavalin A-Sepharose were dialysed against $5 \mathrm{mM}-\mathrm{NH}_{4} \mathrm{HCO}_{3}, \mathrm{pH} 8.0$, and freeze-dried. Samples were prepared for electrophoresis by heating at $100^{\circ} \mathrm{C}$ for $10 \mathrm{~min}$ in $50 \mathrm{~mm}-$ Tris $/ \mathrm{HCl}$, pH6.8, containing $1 \%(\mathrm{w} / \mathrm{v})$ SDS, $1 \%$ (v/v) mercaptoethanol and $10 \%(\mathrm{v} / \mathrm{v})$ glycerol. SDS/polyacrylamide-gel-electrophoretic analysis was performed by using $10 \%(\mathrm{w} / \mathrm{v})$ polyacrylamide slab gels as described by Laemmli (1970). Subunit molecular weights were assigned from the results of parallel separations carried out with the following markers: bovine serum albumin (mol.wt. 68000); bovine liver catalase (mol.wt. 57500); and concanavalin A from jack-bean meal (mol.wt. 27000). After electrophoresis, the gels were stained for protein with Coomassie Brilliant Blue R.

\section{$\left[{ }^{3} \mathrm{H}\right] D F P$ labelling of lipoprotein lipase}

Heparin-Sepharose purified preparations of lipoprotein lipase in $5 \mathrm{~mm}$-sodium barbital, $\mathrm{pH} 7.5$, containing $20 \%(\mathrm{v} / \mathrm{v})$ glycerol and $2 \mathrm{M}-\mathrm{NaCl}$ were used. $\left[1,3-{ }^{3} \mathrm{H}\right] \mathrm{DFP}$ (sp. radioactivity $0.01-0.02 \mathrm{Ci} /$ mmol) and Triton X-100 were added to final concentrations of $1 \mathrm{~mm}$ and $0.1 \%$ respectively. The mixture was gently shaken for $18 \mathrm{~h}$ at $20^{\circ} \mathrm{C}$. Under these conditions, $100 \%$ of the lipoprotein lipase activity was lost in the presence of DFP, whereas in control incubations in its absence the loss of activity was $20 \%$. After exhaustive dialysis against $5 \mathrm{~mm}$ $\mathrm{NH}_{4} \mathrm{HCO}_{3}, \mathrm{pH} 8.0$, and freeze-drying, the samples were analysed by SDS/polyacrylamide-gel electrophoresis.

After staining of the proteins with Coomassie Blue, the gels were cut up into approx. $2 \mathrm{~mm}$ slices and their associated radioactivity was determined by the method of Tishler \& Epstein (1968), using toluene/Triton $X-100(2: 1, v / v)$ containing 2,5diphenyloxazole $(4 \mathrm{~g} /$ litre $)$.

\section{Protein determination}

Protein was determined by the fluorimetric procedure described by Suri et al., (1979). Bovine serum albumin was used to construct a standard curve, which was linear over the range $0-150 \mu \mathrm{g}$ of protein.

\section{Results}

Delipidation of tissues with solvents such as acetone and diethyl ether is frequently used as a preliminary procedure in studies on lipoprotein lipase, since the enzyme is resistant to such treatment. The delipidated tissue is then normally extracted with one of a variety of buffer solutions.

In preliminary studies we therefore investigated a number of conditions for the extraction of lipo- protein lipase from acetone/diethyl ether-dried preparations of rat adipose tissue. The results of two typical experiments are shown in Table 1. The highest lipoprotein lipase activities were achieved in both the homogenate and the supernatant with 5 mM-sodium barbital, pH 7.5, containing $20 \%(\mathrm{v} / \mathrm{v})$ glycerol and $0.1 \%$ (v/v) Triton X-100. A single extraction under such conditions yielded activity in solution equivalent to between 60 and $70 \%$ of a homogenate of the preparation. A second extraction of the tissue residue gave an extract containing $35-45 \%$ of the activity of the first (results not shown), so that after two extractions virtually all of the original activity of the delipidated preparation was brought into solution. In different experiments between 80 and $95 \%$ of these activities were shown to be retained after storage for $24 \mathrm{~h}$ at $4^{\circ} \mathrm{C}$.

In some studies, $0.5 \mathrm{M}$ - to $1.5 \mathrm{M}-\mathrm{NaCl}$ has been reported to increase the proportion of enzyme that is brought into solution from defatted tissue residues (Bensadoun et al., 1974; Chung \& Scanu, 1977). However, in the present work, the presence of $1.5 \mathrm{M}-\mathrm{NaCl}$ did not increase the extract activity above that obtained with sodium barbital and glycerol alone. Moreover, the activity under such conditions declined after storage for $24 \mathrm{~h}$ at $4^{\circ} \mathrm{C}$ to between 8 and $13 \%$ of the initial value (S. M. Parkin, B. K. Speake \& D. S. Robinson, unpublished work). Failure of strong $\mathrm{NaCl}$ solutions to increase the extraction of lipoprotein lipase from delipidated tissue preparations has also been reported for the enzyme in brown adipose tissue (Guerrier \& Pellet, 1979).

An expected problem in the present study was the need to assay lipoprotein lipase at different concentrations of $\mathrm{NaCl}$, since preparations of the enzyme from a variety of sources are widely recognized as being progressively inhibited by increasing concentrations of this salt (Iverius et al., 1972; Greten \& Walter, 1973; Bensadoun et al., 1974; Twu et al., 1975; Ehnholm et al., 1975; Chung \& Scanu, 1977). The extent of inhibition observed depends on the assay conditions and may in certain circumstances be reduced in the presence of heparin, which can itself cause either inhibition or activation of the enzyme, depending on the conditions (Iverius et al., 1972). Accordingly, further preliminary experiments were carried out to investigate the effects of heparin and $\mathrm{NaCl}$ on the expression of rat adipose tissue lipoprotein lipase under the assay conditions used in the present study.

The results of a typical experiment are shown in Fig. 1. Low concentrations of heparin in the absence of added $\mathrm{NaCl}$ produce a slight activation of the enzyme, but its activity is then progressively inhibited at higher heparin concentrations. In the presence of $0.1 \mathrm{M}-\mathrm{NaCl}$, on the other hand, low concentrations of heparin cause a marked stimu- 
Table 1. Extraction of lipoprotein lipase from acetone/diethyl ether-dried preparations of rat adipose tissue In two separate experiments, replicate samples of acetone/diethyl ether-dried preparations of adipose tissue from glucose-fed rats were homogenized in the media indicated. Portions of the homogenates were centrifuged and samples $(60 \mu \mathrm{l})$ of the homogenates and supernatants were assayed for lipoprotein lipase activity as described in the Materials and methods section. The lipolytic activity was inhibited by more than $90 \%$ when the assays were carried out in the presence of $1 \mathrm{M}-\mathrm{NaCl}$.

Extraction medium

$50 \mathrm{mM}-\mathrm{NH}_{3} / \mathrm{NH}_{4} \mathrm{Cl}, \mathrm{pH} 8.1$

$5 \mathrm{~mm}$-Sodium barbital, $\mathrm{pH} 7.5$

$5 \mathrm{~mm}$-Sodium barbital, $\mathrm{pH} 7.5,20 \%$ (v/v) glycerol

$5 \mathrm{~mm}$-Sodium barbital, $\mathrm{pH} 7.5,20 \%$ (v/v) glycerol, $1.5 \mathrm{M}-\mathrm{NaCl}$

5 mM-Sodium barbital, $\mathrm{pH} 7.5,20 \%$ (v/v) glycerol, $0.1 \%(v / v)$ Triton X-100
Lipoprotein lipase activity (units/ml)

\begin{tabular}{|c|c|c|c|}
\hline \multicolumn{2}{|c|}{ Expt. 1} & \multicolumn{2}{|c|}{ Expt. 2} \\
\hline Homogenates & Supernatant & Homogenates & Supernatant \\
\hline $\begin{array}{l}38 \\
45 \\
47 \\
41\end{array}$ & $\begin{array}{l}19 \\
24 \\
21 \\
23\end{array}$ & $\begin{array}{l}44 \\
70 \\
60 \\
46\end{array}$ & $\begin{array}{l}21 \\
33 \\
20 \\
18\end{array}$ \\
\hline 60 & 39 & 76 & 46 \\
\hline
\end{tabular}

lation of the activity of the enzyme. Similar activation by low heparin concentrations also occurs in the presence of $0.3 \mathrm{M}-\mathrm{NaCl}$, although at this last concentration the activity of the enzyme in the absence of heparin is markedly reduced. In the presence of $0.6 \mathrm{M}-\mathrm{NaCl}$, lipoprotein lipase activity is totally inhibited and heparin does not reverse this inhibition.

On the basis of the above results, all subsequent assays of lipoprotein lipase in solutions that also contained $\mathrm{NaCl}$ were carried out in the presence of heparin $(0.5 \mathrm{unit} / \mathrm{ml})$ and under conditions where the $\mathrm{NaCl}$ concentrations in the assay were never greater than $0.3 \mathrm{M}$. Whenever accurate estimates of enzyme recoveries were required, appropriate correction factors, derived from four experiments similar to that shown in Fig. 1, were applied to the lipoprotein lipase activity measurements.

Since Triton X-100 was present in many of the buffer solutions used in the present work, its effect on the expression of lipoprotein lipase activity in the assay was also studied, in view of reports of the activation of the enzyme by detergents (Kinnunen et al., 1976). At a concentration of $0.1 \%$, Triton X-100 inhibited enzyme activity by about $50 \%$ but it had no effect at concentrations of $0.03 \%$ or below. Nor at this concentration did it affect the $\mathrm{NaCl} /$ heparin profiles shown in Fig. 1. Triton X-100 concentrations in the assay were always below $0.03 \%$.

\section{Heparin-Sepharose chromatography of rat adipose tissue lipoprotein lipase}

Binding of lipoprotein lipase on columns of heparin-Sepharose, followed by its elution with concentrations of $\mathrm{NaCl}$ greater than $1 \mathrm{M}$, has been used previously to purify the enzyme from a variety of sources. Fig. 2 shows a characteristic elution profile of the enzyme when extracts of acetone/ diethyl ether-dried preparations of rat adipose tissue were applied to columns of heparin-Sepharose and eluted sequentially with $0.7 \mathrm{M}-$ and $2.0 \mathrm{M}-\mathrm{NaCl}$ solutions in the present study. A single sharp peak of enzyme activity is eluted with $2.0 \mathrm{M}-\mathrm{NaCl}$.

Concentrations of $1.0-1.5 \mathrm{M}-\mathrm{NaCl}$ were found in separate experiments to elute the enzyme as a broader, but still single, peak. On some occasions a small variable proportion of activity did not bind to the column, as reported by others for enzyme from other sources (Egelrud \& Olivecrona, 1972; Twu et al., 1975; Ehnholm et al., 1975).

The recovery and the specific activity of the eluted enzyme in the experiment of Fig. 2 were respectively $40 \%$ and 14900 units $/ \mathrm{mg}$ of protein, representing a purification of 3600 -fold over that of the enzyme in the applied extract. In a total of 30 other similar experiments purifications have ranged between 600 - and 4000-fold.

\section{Stability of heparin-Sepharose-purified lipoprotein lipase}

Table 2 shows the results of experiments that were carried out to study the effects of glycerol and Triton $\mathrm{X}-100$ on the stability of the heparin-Sepharosepurified enzyme during storage in the presence of $2 \mathrm{M}-\mathrm{NaCl}$ at $4^{\circ} \mathrm{C}$ and $\mathrm{pH}$ 7.5. A rapid decay in the absence of either $20 \%(\mathrm{v} / \mathrm{v})$ glycerol or $0.1 \%(\mathrm{v} / \mathrm{v})$ Triton X-100, and very marked stabilization in the presence of both, was observed. At $18^{\circ} \mathrm{C}$ the enzyme was more unstable than at $4^{\circ} \mathrm{C}$ but, even at this higher temperature, the half-life in the presence of $5 \mathrm{~mm}$-sodium barbital buffer, $\mathrm{pH} 7.5$, containing $20 \%(\mathrm{v} / \mathrm{v})$ glycerol, $0.1 \%(\mathrm{v} / \mathrm{v})$ Triton $\mathrm{X}-100$ and $2 \mathrm{M}-\mathrm{NaCl}$, was still over $40 \mathrm{~h}$ (results not shown). 


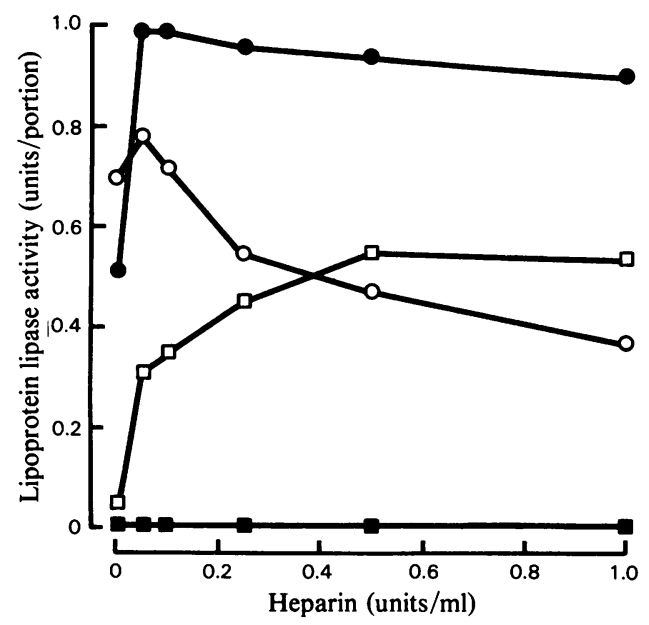

Fig. 1. Effect of heparin concentration on the expression of rat adipose tissue lipoprotein lipase activity at different concentrations of $\mathrm{NaCl}$

An acetone/diethyl ether-dried preparation of adipose tissue from glucose-fed rats was extracted with $5 \mathrm{~mm}$-sodium barbital, pH 7.5, containing $20 \%$ (v/v) glycerol as described in the Materials and methods section. The lipoprotein lipase activity of portions $(25 \mu \mathrm{l})$ of the extract was measured in the presence of increasing concentrations of heparin at $0 \mathrm{M}-(\mathrm{O})$, $0.1 \mathrm{M}-(\bigcirc), 0.3 \mathrm{M}-(\square)$ and $0.6 \mathrm{M}-\mathrm{NaCl}(\square)$.

Moreover, in such a medium, over $80 \%$ of the enzyme activity remained after storage for 8 weeks at $-70^{\circ} \mathrm{C}$.

Electrophoresis of heparin-Sepharose-purified lipoprotein lipase on SDS/polyacrylamide gels

Several groups of workers have reported that, after affinity chromatography on heparinSepharose, lipoprotein lipase preparations from a variety of tissue sources display a single major component when analysed by SDS/polyacrylamidegel electrophoresis. The subunit molecular weights assigned to this component have varied between 55000 and 74000 (Egelrud \& Olivecrona, 1972; Bensadoun et al., 1974; Twu et al., 1975, 1976; Bensadoun \& Kompiang, 1979). However, ÖstlundLindqvist \& Boberg (1977) have reported in their studies on lipoprotein lipase in human post-heparin plasma that antithrombin-III, which has a mol.wt. of about 65000 (Miller-Andersson et al., 1974), also binds to columns of heparin-Sepharose and is eluted by $\mathrm{NaCl}$ at concentrations of $0.7-1.5 \mathrm{M}$. Lipoprotein lipase preparations purified from postheparin plasma by heparin-Sepharose chromatography are, therefore, heavily contaminated (90\%) with antithrombin-III. Clearly, in these circum-

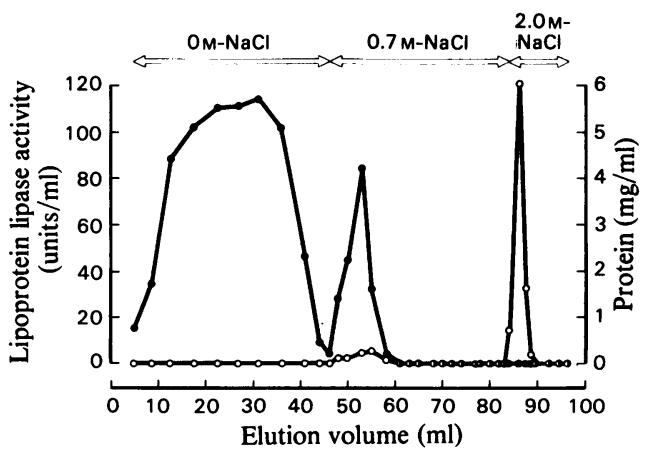

Fig. 2. Heparin-Sepharose chromatography of rat adipose tissue lipoprotein lipase

An acetone/diethyl ether-dried preparation of adipose tissue from glucose-fed rats was extracted with 5 mM-sodium barbital, $\mathrm{pH} 7.5$, containing $20 \%$ $(\mathrm{v} / \mathrm{v})$ glycerol and $0.1 \%(\mathrm{v} / \mathrm{v})$ Triton $\mathrm{X}-100$ as described in the Materials and methods section. A portion of the extract $(40 \mathrm{ml})$ was applied to a column of heparin-Sepharose $(10 \mathrm{ml}$ column volume) equilibrated with $5 \mathrm{~mm}$-sodium barbital, pH 7.5, containing $20 \%(\mathrm{v} / \mathrm{v})$ glycerol. The column was washed with $1 \mathrm{vol}$. of the equilibration buffer and then with $4 \mathrm{vol}$. of the same buffer containing $0.7 \mathrm{M}-\mathrm{NaCl}$. Finally, lipoprotein lipase was eluted at a rate of $20 \mathrm{ml} / \mathrm{h}$ with $5 \mathrm{mM}$-sodium barbital, $\mathrm{pH} 7.5$, containing $20 \%(\mathrm{v} / \mathrm{v})$ glycerol and $2 \mathrm{M}-\mathrm{NaCl}$. Fractions $(2-5 \mathrm{ml})$ of the eluate were collected throughout and portions were assayed immediately for both enzyme activity $(0)$ and protein $(O)$. The activities shown have been corrected for the effects of $\mathrm{NaCl}$ and heparin on the assay.

stances the possibility that the enzyme purified from other tissues by this procedure may be similarly contaminated needs to be examined.

The lipoprotein lipase preparations eluted from the heparin-Sepharose column with $5 \mathrm{~mm}$-sodium barbital, pH 7.5, containing $20 \%(\mathrm{v} / \mathrm{v})$ glycerol and $2 \mathrm{M}-\mathrm{NaCl}$ were analysed by SDS/polyacrylamide-gel electrophoresis (Fig. 3a). Two major bands, corresponding to mol.wts. 62000 and 56000 , were routinely observed. A variable number of other minor bands were sometimes present (see, for example, Fig. 7), similar to those reported by others (Kinnunen et al., 1976; Östlund-Lindqvist \& Boberg, 1977; Östlund-Lindqvist, 1979).

\section{Identification of lipoprotein lipase on SDS/poly- acrylamide gels}

The results in Fig. 3(a) do not allow any definitive conclusions to be reached concerning which, if either, of the major bands is due to lipoprotein lipase. Accordingly, further experiments were carried out to throw light on this matter. 
Table 2. Stability of heparin-Sepharose-purified lipoprotein lipase in the presence of $2 \mathrm{M}-\mathrm{NaCl}$ An acetone/diethyl ether-dried preparation of adipose tissue from glucose-fed rats was extracted with 5 mM-sodium barbital, $\mathrm{pH} 7.5$, containing $20 \%(\mathrm{v} / \mathrm{v})$ glycerol and $0.1 \%(\mathrm{v} / \mathrm{v})$ Triton X-100 as described in the Materials and methods section. Portions $(7 \mathrm{ml})$ of the extract were applied to each of four heparin-Sepharose columns $(6 \mathrm{ml}$ column vol.), which were washed with 3 vol. of 5 mM-sodium barbital, $\mathrm{pH} 7.5$, containing $20 \%$ (v/v) glycerol and $0.7 \mathrm{M}-\mathrm{NaCl}$. Lipoprotein lipase was then eluted with sodium barbital buffer solutions having the composition indicated in the Table. Equivalent fractions containing lipoprotein lipase were collected from each column and were kept at $4^{\circ} \mathrm{C}$ for the times shown before being assayed for lipoprotein lipase.

Lipoprotein lipase activity

Eluting buffer solution

5 mM-Sodium barbital, $\mathrm{pH} 7.5,2 \mathrm{M}-\mathrm{NaCl}$ (units/ml) remaining after:

5 mM-Sodium barbital, pH 7.5, $20 \%$ (v/v) glycerol, $2 \mathrm{M}-\mathrm{NaCl}$

5 mM-Sodium barbital, $\mathrm{pH} 7.5,0.1 \%(\mathrm{v} / \mathrm{v})$

\begin{tabular}{ccc}
\hline $0 \mathrm{~h}$ & $24 \mathrm{~h}$ & $48 \mathrm{~h}$ \\
28 & 9 & 5 \\
27 & 20 & 12 \\
28 & 23 & 16 \\
37 & 36 & 33
\end{tabular}

5 mM-Sodium barbital, $\mathrm{pH} 7.5,20 \%$ (v/v) glycerol, $\quad 37 \quad 36 \quad 33$

$0.1 \%(\mathrm{v} / \mathrm{v})$ Triton X-100, $2 \mathrm{M}-\mathrm{NaCl}$
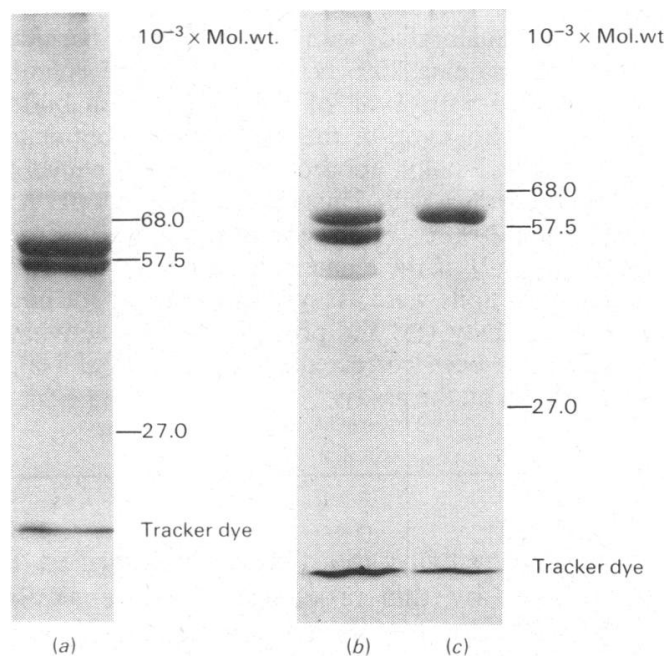

Fig. 3. SDS/polyacrylamide-gel electrophoresis of adipose tissue lipoprotein lipase purified by heparinSepharose chromatography

Lipoprotein lipase samples eluted from heparinSepharose columns with $5 \mathrm{~mm}$-sodium barbital, $\mathrm{pH} 7.5$, containing $20 \%(\mathrm{v} / \mathrm{v})$ glycerol and $2 \mathrm{M}$ $\mathrm{NaCl}$, were dialysed against $5 \mathrm{mM}-\mathrm{NH}_{4} \mathrm{HCO}_{3}$, $\mathrm{pH} \mathrm{8.0,} \mathrm{and} \mathrm{freeze-dried.} \mathrm{Samples} \mathrm{were} \mathrm{prepared} \mathrm{for}$ electrophoresis as described in the Materials and methods section. (a) Enzyme was prepared from $0.3 \mathrm{~g}$ of acetone/diethyl ether-dried powder from glucose-fed rats and $50 \mu \mathrm{g}$ of protein was loaded on the gel; In $(b)$ and $(c)$, enzyme was prepared from $0.23 \mathrm{~g}$ of acetone/diethyl ether-dried powder from either glucose-fed (b) or $48 \mathrm{~h}$-starved (c) rats from the same batch and $30 \mu \mathrm{g}$ or $18 \mu \mathrm{g}$ of protein respectively was loaded on the gel. Migration of the marker proteins is indicated from top to bottom $\left(10^{-3} \times\right.$ mol.wt.): bovine serum albumin $(68000)$; catalase (57500); concanavalin A (27000).

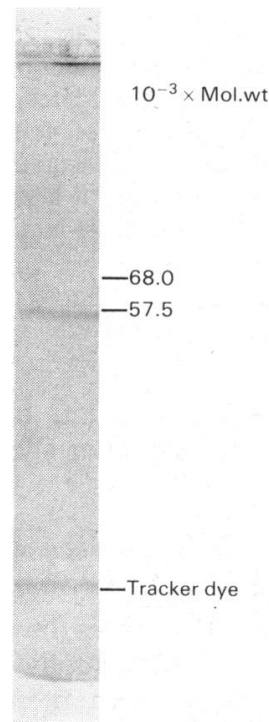

Fig. 4. SDS/polyacrylamide-gel electrophoresis of adipose tissue lipoprotein lipase after purification by low-antithrombin-affinity heparin-Sepharose chromatography

The experiment was carried out as described in the legend to Fig. 3 but using heparin with a low affinity for antithrombin to prepare the heparin-Sepharose. The lipoprotein lipase was prepared from $0.06 \mathrm{~g}$ of acetone/diethyl ether-dried powder from glucose-fed rats and $5 \mu \mathrm{g}$ of protein was loaded on the gel.

Comparison of lipoprotein lipase preparations from fed and starved rats. Rat adipose tissue lipoprotein lipase activity is much lower in starved than in fed animals (Robinson, 1970) and there 


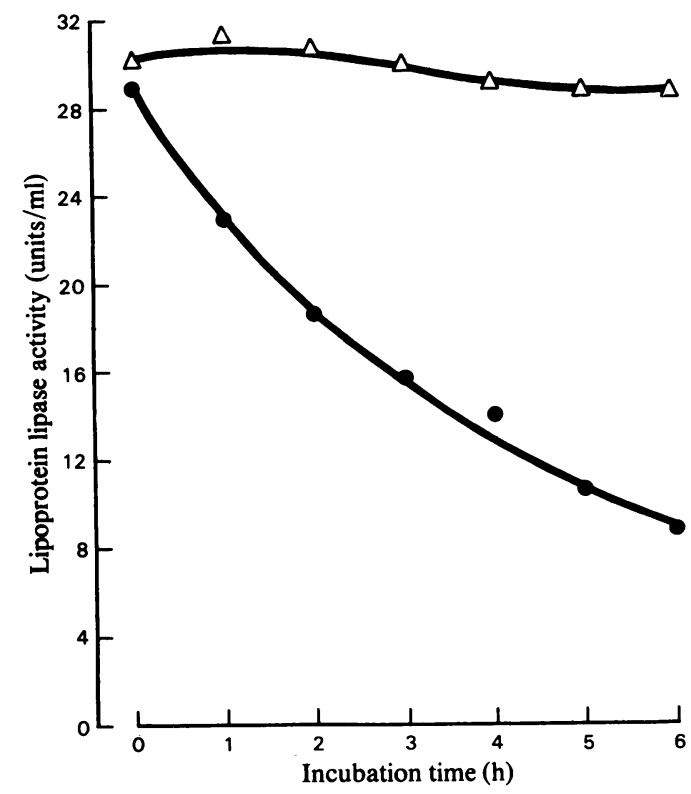

Fig. 5. Inhibition of lipoprotein lipase by DFP An acetone/diethyl ether-dried preparation of adipose tissue from glucose-fed rats was extracted with 5 mm-sodium barbital, pH 7.5, containing $20 \%$ (v/v) glycerol and $0.1 \%$ (v/v) Triton $\mathrm{X}-100$, as described in the Materials and methods section. Portions of the extract were incubated at $30^{\circ} \mathrm{C}$ in the presence $(\bullet)$ or absence $(\Delta)$ of $1 \mathrm{mM}$-DFP. Samples were taken at the times shown and assayed for lipoprotein lipase activity.

is immunological evidence that the amount of the enzyme protein falls on starvation (Jansen et al., 1978). Heparin-Sepharose-purified lipoprotein lipase was, therefore, prepared from adipose tissue of glucose-fed and $48 \mathrm{~h}$-starved rats and the preparations were analysed by SDS/polyacrylamide-gel electrophoresis. On staining with Coomassie Blue, preparations from glucose-fed animals (Fig. $3 b$ ) showed two major bands with apparent mol.wts. of 62000 and 56000 . In preparations from starved animals (Fig. 3c), the intensity of staining of the 62000 -mol.wt. band was unchanged, whereas that of the 56000-mol.wt. band was greatly reduced.

Use of heparin with a low affinity for antithrombin. In order to prepare antithrombin-free lipoprotein lipase from post-heparin plasma, ÖstlundLindqvist \& Boberg (1977) used heparin-Sepharose columns prepared with fractionated heparin that had a low affinity for antithrombin. We have employed similar low-affinity heparin-Sepharose columns in the present study. When extracts of acetone/diethyl ether-dried preparations of adipose tissue from glucose-fed rats were fractionated on such columns, lipoprotein lipase was again eluted in a single sharp peak with $2 \mathrm{M}-\mathrm{NaCl}$. However, when SDS/polyacrylamide-gel electrophoresis of the purified enzyme was carried out, only a single band of apparent mol.wt. 56000 was stained with Coomassie Blue (Fig. 4).

Use of ${ }^{3} \mathrm{H}$-labelled DFP. Rat heart lipoprotein lipase activity has been reported to be inhibited completely by $1 \mathrm{mM}$-DFP (Chung \& Scanu, 1977). This has been confirmed for the enzyme in rat adipose tissue in the present study (Fig. 5).

The inhibition of lipoprotein lipase by DFP presumably reflects a covalent interaction of the inhibitor with a serine group at the active site of the enzyme. On this assumption, experiments were carried out in which heparin-Sepharose-purified preparations of the enzyme from both glucose-fed and $48 \mathrm{~h}$-starved rats were exposed to ${ }^{3} \mathrm{H}$-labelled DFP and then analysed by SDS/polyacrylamide-gel electrophoresis. The results in Fig. 6 show that, in both preparations, most of the $\left[{ }^{3} \mathrm{H}\right] \mathrm{DFP}$ radioactivity is associated with the gel band of apparent mol.wt. 56000, apparent only in the preparation from glucose-fed rats, rather than with the 62000mol.wt. polypeptide band. Moreover, when the total counts associated with the 56000-mol.wt. band in the preparations from glucose-fed and $48 \mathrm{~h}$-starved rats are compared, the ratio is approximately the same $(5: 1)$ as that of the lipoprotein lipase activities of the original extracts of the acetone/diethyl ether-dried preparations.

A small amount of the ${ }^{3} \mathrm{H}$-labelled DFP was associated with bands corresponding to polypeptides with apparent mol.wts. of 46000 and 27000 in this experiment. In five similar experiments, the proportion so associated has varied between 5 and $30 \%$. The staining of the $62000-\mathrm{mol}$.wt. polypeptide relative to that of the 56000 -mol.wt. polypeptide in the enzyme preparation from glucose-fed rats was considerably greater in this experiment than in the experiments shown in Fig. 3. This could reflect a greater degree of antithrombin contamination (see the Discussion section).

\section{Chromatography of purified lipoprotein lipase preparation on concanavalin A-Sepharose}

Chromatography on concanavalin A-Sepharose has been widely used in the purification of lipoprotein lipase from a variety of sources (NilssonEhle et al., 1980). In the present study, enzyme preparations eluted from heparin-Sepharose columns with $2 \mathrm{M}-\mathrm{NaCl}$ have been further fractionated on concanavalin A-Sepharose. A typical elution profile is shown in Fig. 7. Over $90 \%$ of the applied enzyme activity was bound and approx. $45 \%$ of the bound enzyme activity was eluted in a single 

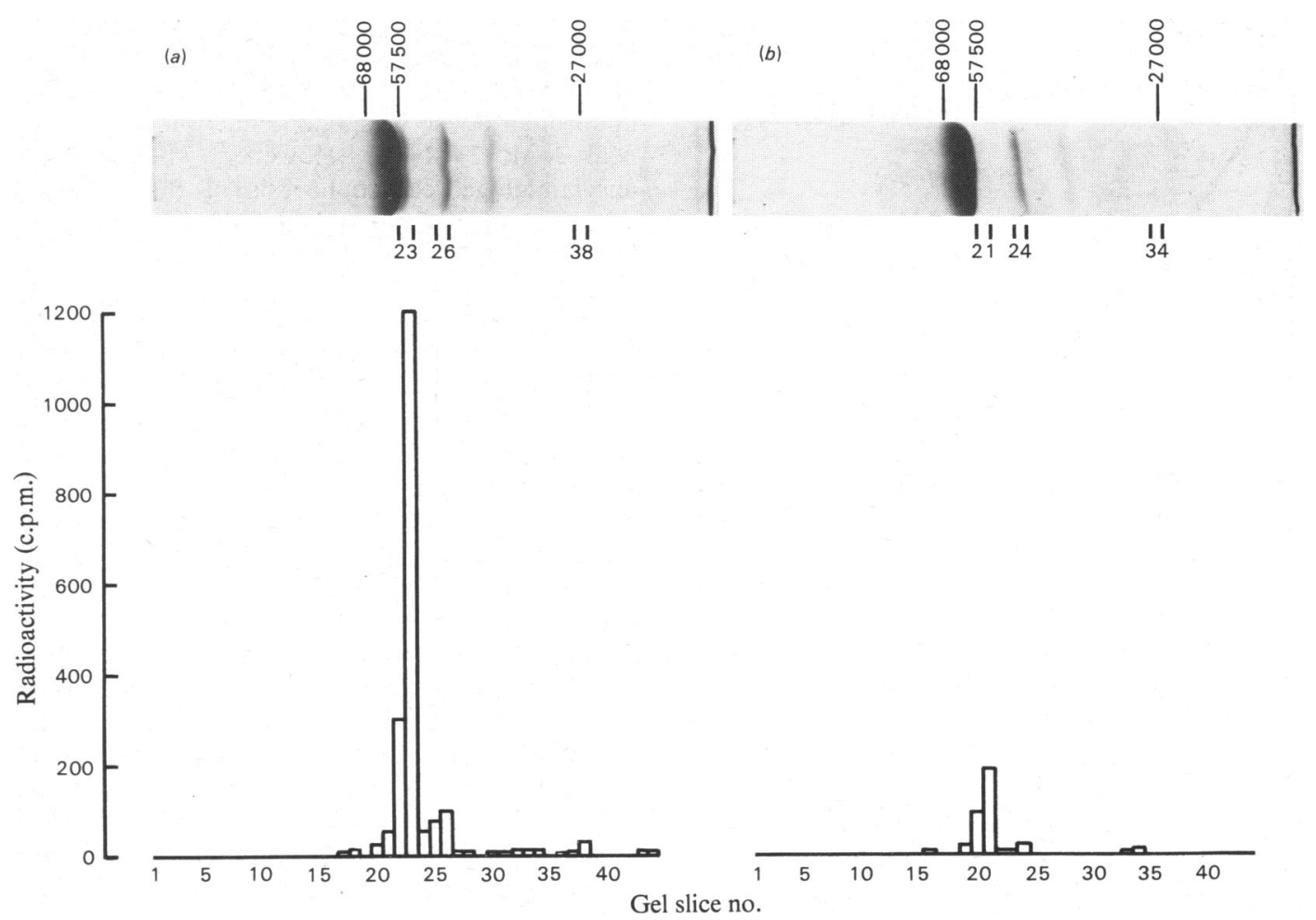

Fig. 6. Analysis of ${ }^{3} \mathrm{H}$-labelled-DFP-treated preparation of lipoprotein lipase by SDS/polyacrylamide-gel electrophoresis Acetone/diethyl ether-dried preparations of adipose tissue from equal numbers $(20)$ of glucose-fed and $48 \mathrm{~h}$-starved rats were extracted under equivalent conditions with $5 \mathrm{mM}$-sodium barbital, $\mathrm{pH} 7.5$, containing $20 \%$ (v/v) glycerol and $0.1 \%(\mathrm{v} / \mathrm{v})$ Triton X-100. Equivalent samples of the extracts, containing respectively 960 and 190 units of lipoprotein lipase, were fractionated on heparin-Sepharose columns as described in the Materials and methods section. Lipoprotein lipase was eluted with $5 \mathrm{~mm}$-sodium barbital, $\mathrm{pH} 7.5$, containing $20 \%(\mathrm{v} / \mathrm{v})$ glycerol and $2 \mathrm{M}-\mathrm{NaCl}$ and treated with $\left[1,3-{ }^{3} \mathrm{H}\right] \mathrm{DFP}$ (sp. radioactivity $0.02 \mathrm{Ci} / \mathrm{mmol}$ ) at $1 \mathrm{mM}$ as described in the Materials and methods section. The two preparations were then dialysed exhaustively against $5 \mathrm{mM}-\mathrm{NH}_{4} \mathrm{HCO}_{3}, \mathrm{pH} 8.0$, and freeze-dried. They were then subjected to SDS/polyacrylamide-gel electrophoresis and, after staining, the gels were sliced and the radioactivity of the slices was determined as described in the Materials and methods section. (a) and (b) show the distribution along the gels of the radioactivity of the $\left[1,3-{ }^{3} \mathrm{H}\right]$ DFP-labelled lipoprotein lipase preparations from glucose-fed and $48 \mathrm{~h}$-starved rats respectively. The positions of migration of the Coomassie-staining bands are also shown and the migration of marker proteins is indicated: bovine serum albumin (68000); catalase (57500); concanavalin A (27000).

peak by a solution of $0.6 \mathrm{M}$-methyl $\alpha$-D-mannoside and $0.6 \mathrm{M}$-methyl $\alpha$-D-glucoside. Analysis of the column fractions by SDS/polyacrylamide-gel electrophoresis showed that a substantial proportion of the polypeptide of mol.wt. 62000 present in the applied solution was not bound by the column. However, the bound fraction that was eluted with glycosides still yielded a gel pattern displaying this polypeptide as well as that of mol.wt. 56000 (Fig. 8). The specific activity of the enzyme eluted from concanavalin A-Sepharose was 15500 units/mg of protein, over 3-fold that of the applied enzyme fraction (4700 units/mg of protein).

\section{Discussion}

Various buffer solutions have been employed to extract lipoprotein lipase from defatted tissue residues, the most frequently employed being $25-$ $50 \mathrm{mM}-\mathrm{NH}_{3} / \mathrm{NH}_{4} \mathrm{Cl}$ at $\mathrm{pH} 8.1-8.5$ and $5 \mathrm{mM}$-sodium barbital at pH 7.2-7.4 (see, for example, Bensadoun et al., 1974; Twu et al., 1975; Chung \& Scanu, 1977). Glycerol is often present in the buffer solution, because of its ability to stabilize the extracted enzyme (Guidicelli \& Boyer, 1973; Bensadoun et al., 1974; Ehnholm et al., 1975; Twu et al., 1975; Iverius \& Östlund-Lindqvist, 1976; Chung \& Scanu, 1977). Detergents have been shown to increase extraction of the enzyme from aqueous tissue residues (Borensztajn et al., 1970) and to decrease its binding to hydrophobic surfaces (Kinnunen et al., 1976; Kinnunen, 1977; Bengtsson \& Olivecrona, 1977). However, although they have also been reported to stabilize the enzyme in solution (Baginsky \& Brown, 1977; Bengtsson \& Olivecrona, 


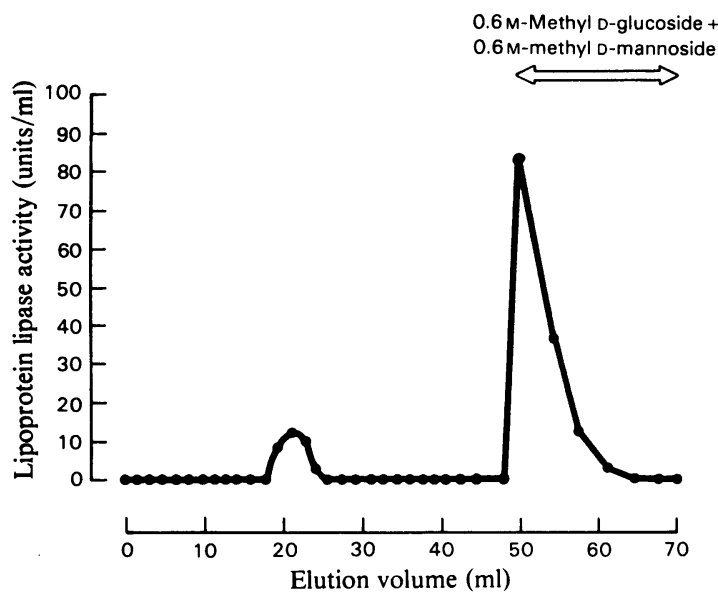

Fig. 7. Fractionation of rat adipose tissue lipoprotein lipase on concanavalin A-Sepharose

Lipoprotein lipase extracted from acetone/diethyl ether-dried preparations of glucose-fed rats was fractionated on heparin-Sepharose columns and eluted with $2 \mathrm{M}-\mathrm{NaCl}$ in $5 \mathrm{~mm}$-sodium barbital, pH 7.5, containing $20 \%(\mathrm{v} / \mathrm{v})$ glycerol, as described in the Materials and methods section. A portion $(15 \mathrm{ml})$ of the eluate containing 1100 units of lipoprotein lipase was applied to a concanavalin A-Sepharose column ( $5 \mathrm{ml}$ column vol.) equilibrated with $5 \mathrm{~mm}$-sodium barbital, $\mathrm{pH} 7.5$, containing $20 \%(\mathrm{v} / \mathrm{v})$ glycerol, $1 \mathrm{M}-\mathrm{NaCl}, 5 \mathrm{~mm}-\mathrm{CaCl}_{2}$ and $5 \mathrm{~mm}-\mathrm{MnCl}_{2}$. After washing with equilibration buffer, lipoprotein lipase was eluted with this buffer containing $0.6 \mathrm{M}$-methyl $\alpha$-D-glucoside and $0.6 \mathrm{M}$ methyl $\alpha$-D-mannoside. Fractions $(2-4 \mathrm{ml})$ were collected and assayed for lipoprotein lipase activity as described in the Materials and methods section.

1979; Becht et al., 1980), they have not so far been studied with respect to their ability to solubilize the enzyme after tissue delipidation. The results of the present study show that virtually all the enzyme can be extracted from delipidated rat adipose tissue preparations by two extractions of $0.1 \%(\mathrm{v} / \mathrm{v})$ Triton $\mathrm{X}-100$ in $5 \mathrm{mM}$-sodium barbital buffer containing $20 \%(\mathrm{v} / \mathrm{v})$ glycerol at $\mathrm{pH} 7.5$. Since such a medium also substantially stabilizes the heparin-Sepharosepurified enzyme at $4^{\circ} \mathrm{C}$, it provides a useful addition to the extractant solutions presently available.

The behaviour of rat adipose tissue lipoprotein lipase on heparin-Sepharose columns reported here (Fig. 2) is generally similar to that described for the enzyme in other tissues. The only previous work on the rat adipose tissue enzyme is that of Greten \& Walter (1978) and of Etienne et al. (1976). Whereas Greten \& Walter (1978) reported elution of the enzyme from heparin-Sepharose columns by $1.2 \mathrm{M}$ $\mathrm{NaCl}$ as a single peak, in agreement with the results

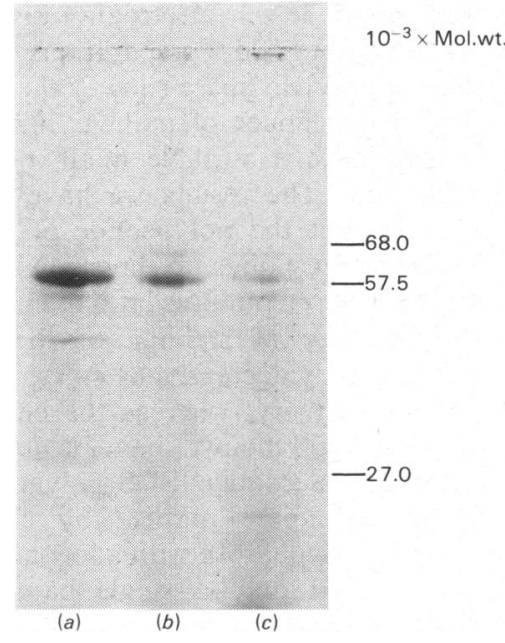

Fig. 8. SDS/polyacrylamide-gel electrophoresis of concanavalin A-Sepharose-purified lipoprotein lipase Lipoprotein lipase purified by affinity chromatography on heparin-Sepharose and then by concanavalin A-Sepharose chromatography, as described in the legend to Fig. 7, was dialysed against $5 \mathrm{mM}$ $\mathrm{NH}_{4} \mathrm{HCO}_{3}, \mathrm{pH} 8.0$, freeze-dried and analysed by SDS/polyacrylamide-gel electrophoresis as described in the Materials and methods section. Samples of heparin-Sepharose-purified enzyme and of unbound fractions from the concanavalin ASepharose column were also analysed. (a) HeparinSepharose-purified lipoprotein lipase; (b) wash from concanavalin A-Sepharose column with $5 \mathrm{mM}^{-}$ sodium barbital, pH7.5, containing $20 \%$ (v/v) glycerol, $1 \mathrm{M}-\mathrm{NaCl}, 5 \mathrm{~mm}-\mathrm{CaCl}_{2}$ and $5 \mathrm{~mm}-\mathrm{MnCl}_{2}$; (c) lipoprotein lipase eluted from concanavalin A-Sepharose column with 5 mm-sodium barbital, $\mathrm{pH} 7.5$, containing $20 \%(\mathrm{v} / \mathrm{v})$ glycerol. $1 \mathrm{M}-\mathrm{NaCl}$, $5 \mathrm{mM}-\mathrm{CaCl}_{2}, 5 \mathrm{mM}-\mathrm{MnCl}_{2}$. $0.6 \mathrm{M}$-methyl $\alpha$-D-glucoside and $0.6 \mathrm{M}$-methyl $\alpha$-D-mannoside. Migration of marker proteins is indicated, from top to bottom $\left(10^{-3} \times\right.$ mol.wt.): bovine serum albumin (68000); catalase (57 500); concanavalin A (27000).

reported here, Etienne et al. (1976) described the elution of two peaks of activity with $1.16 \mathrm{M}-\mathrm{NaCl}$. Only the first of these, however, showed a requirement for serum in the assay medium and inhibition of the enzyme's activity in the assay by $1 \mathrm{M}-\mathrm{NaCl}$, properties that are generally recognized as being characteristic of lipoprotein lipase. All the enzyme activity eluted from heparin-Sepharose columns with $2 \mathrm{M}-\mathrm{NaCl}$ in the present study was inhibited by over $90 \%$ in the presence of $1 \mathrm{M}-\mathrm{NaCl}$ in the assay and consistently appeared in a single peak, whether obtained from the adipose tissue of animals that were in the fed or, as in the experiments of Etienne $e t$ al. (1976), starved state. 
SDS/polyacrylamide-gel electrophoresis of the heparin-Sepharose-purified preparations of rat adipose tissue lipoprotein lipase showed the presence of two major polypeptides of mol.wts. 62000 and 56000 , together with a variable number of other minor components. The results we have obtained strongly suggest that the polypeptide of apparent mol.wt. 56000 corresponds to lipoprotein lipase. This conclusion is based on three lines of evidence.

First, the intensity of staining of the 56000mol.wt. band is greatly decreased by starvation, as is lipoprotein lipase activity, whereas the intensity of staining of the 62000 -mol.wt. band is unchanged (Figs. $3 b$ and $3 c$ ). Secondly, SDS/polyacrylamide gels of lipoprotein lipase purified by chromatography on heparin-Sepharose with a low affinity for antithrombin showed only a single band corresponding to a polypeptide of mol.wt. 56000 (Fig. 4). The lack of binding of the 62000-mol.wt. polypeptide to such heparin-Sepharose suggests that this polypeptide is antithrombin-III, which has a molecular weight in the region of 65000 (MillerAndersson et al., 1974). This has already been shown to contaminate lipoprotein lipase purified from human post-heparin plasma (ÖstlundLindqvist \& Boberg, 1977; Thim, 1978) and could well contaminate preparations of the enzyme from other sources. The variations noted in the present study in the amount of the 62000-mol.wt. polypeptide relative to that of the 56000 -mol.wt. polypeptide would be consistent with this, since differences could occur in the extent of contamination of the fat-bodies with blood proteins on their removal from the animals.

The final line of evidence derives from the ability of DFP to inactivate lipoprotein lipase in heparinSepharose-purified preparations and from the association of ${ }^{3} \mathrm{H}$-labelled DFP with the 56000 -mol.wt. band rather than with the 62000 -mol.wt. band, as shown in Fig. 6. In the experiments with $\left[{ }^{3} \mathrm{H}\right]$ DFP some of the radioactivity was associated with peptides of mol.wts. 46000 and 27000 . However, the proportion of the total radioactivity in these fractions was always small and was the same for 'glucose-fed' and ' $48 \mathrm{~h}$-starved' preparations. It is possible that these lower-molecular-weight peptides are produced by proteolysis of the lipoprotein lipase during its purification.

Although several studies on the purification of lipoprotein lipase from a variety of sources have been described, there is no general agreement in the literature as to the minimum molecular weight of the enzyme. Thus, although values ranging from 55000 to 74000 have been widely reported on the basis of SDS/polyacrylamide-gel separations (see, for example, review by Nilsson-Ehle et al., 1980), substantially lower molecular-weights for the enzyme have also been claimed (Fielding et al., 1974; Chung \&
Scanu, 1977; Clegg, 1979). Although some of the differences may represent real interspecies or interorgan variations, there are also discrepancies amongst studies on the enzyme from a single source (Twu et al., 1975; Chung \& Scanu, 1977). We suggest that some of these discrepancies may be due to contamination of the enzyme with antithrombin and/or to the action of endogenous proteinases during purification.

We thank Mrs. Diane Bennett, Mr. Andrew Leadbeatter and Mr. Christopher Parkinson for their excellent assistance and Dr. E. Holmer for the gift of heparin with a low affinity for antithrombin. The work was supported by a grant from the Medical Research Council.

\section{References}

Agrawal, B. \& Goldstein, C. (1967) Biochim. Biophys. Acta 147, 262-271

Ashby, P. \& Robinson, D. S. (1980) Biochem. J. 188, 185-192

Ashby, P., Tolson, A. M. \& Robinson, D. S. (1978a) Biochem.J. 171, 305-311

Ashby, P., Bennett, D. P., Spencer, I. M. \& Robinson, D. S. (1978b) Biochem. J. 176, 865-872

Baginsky, M. L. \& Brown, W. V. (1977) J. Lipid Res. 18, 423-437

Becht, I., Schrecker, O., Klose, G. \& Greten, H. (1980) Biochim. Biophys. Acta 620, 583-591

Bengtsson, G. \& Olivecrona, T. (1977) Biochem. J. 167, 109-119

Bengtsson, G. \& Olivecrona, T. (1979) Biochim. Biophys. Acta 575, $471-474$

Bensadoun, A. \& Kompiang, I. P. (1979) Fed. Proc. Fed. Am. Soc. Exp. Biol. 381, 2622-2626

Bensadoun, A., Ehnholm, C., Steinberg, D. \& Brown, W. V. (1974) J. Biol. Chem. 249, 2220-2227

Borensztajn, J., Otway, S. \& Robinson, D. S. (1970) J. Lipid Res. 11, 102-110

Chung, J. \& Scanu, A. M. (1977) J. Biol. Chem. 252 , 4202-4209

Clegg, R. A. (1979) Biochem. Soc. Trans. 7, 1053-1054

Cryer, A., Riley, S. E., Williams, E. R. \& Robinson, D. S. (1976) Clin. Sci. Mol. Med. 50, 213-221

Egelrud, T. \& Olivecrona, T. (1972) J. Biol. Chem. 247, 6212-6217

Ehnholm, C., Kinnunen, P., Huttenen, J., Nikkilä, E. \& Ohta, M. (1975) Biochem. J. 149, 649-655

Etienne, J., Breton, M., Vanhove, A. \& Polonovski, J. (1976) Biochim. Biophys. Acta 429, 199-204

Fielding, P. E., Shore, V. G. \& Fielding, C. J. (1974) Biochemistry 13, 4318-4323

Greten, H. \& Walter, B. (1973) FEBS Lett. 35, 36-40

Guerrier, D. \& Pellet, H. (1979) FEBS Lett. 106, $115-120$

Guidicelli \& Boyer (1973) J. Lipid Res. 14, 592-595

Hamosh, M., Clary, T. R., Chernick, S. S. \& Scow, R. O. (1970) Biochim. Biophys. Acta 210, 473-482

Iverius, P-H. \& Östlund-Lindqvist, A.-M. (1976) J. Biol. Chem. 251, 7791-7795

Iverius, P-H., Lindahl, U., Egelrud, T. \& Olivecrona, T. (1972) J. Biol. Chem. 247, 6610-6616 
Jansen, H., Garfinkel, A. S., Twu, J.-S., Nikazy, J. \& Schotz, M. C. (1978) Biochim. Biophys. Acta 531, 109-114

Kinunnen, P. K. J. (1977) Med. Biol. 55, 187-191

Kinnunen, P. K. J., Huttunen, J. K., Ehnholm, C. (1976) Biochim. Biophys. Acta 150, 342-351

Laemmli, U. K. (1970) Nature (London) 227, 680-685

Miller-Andersson, M., Borg, H. \& Andersson, L.-O. (1974) Thromb. Res. 5, 439-452

Nilsson-Ehle, P., Garfinkel, A. S. \& Schotz, M. C. (1980) Adv. Lipid Res. 49, 667-693

Östlund-Lindqvist, A.-M. (1979) Biochem. J. 179, 555559

Östlund-Lindqvist, A.-M. \& Boberg, J. (1977) FEBS Lett. 83, 231-236

Otway, S. \& Robinson, D. S. (1968) Biochem. J. 106, 677-682
Parkin, S. M., Walker, K., Ashby, P. \& Robinson, D. S. (1980) Biochem. J. 188, 193-199

Porath, J., Aspberg, K., Dreven, H. \& Axen, R. (1973) J. Chromatogr. 86, 53-54

Riley, S. E. \& Robinson, D. S. (1974) Biochim. Biophys. Acta 369, 371-386

Robinson, D. S. (1970) Compr. Biochem. 18, 51-116

Suri, B., Targ, M. \& Robinson, D. S. (1979) Biochem. J. $178,455-466$

Thim, L. (1978) Scand. J. Clin. Lab. Invest. 381, 77-81

Tishler, P. V. \& Epstein, C. J. (1968) Anal. Biochem. 22, 89-98

Twu, J.-S., Garfinkel, A. S. \& Schotz, M. C. (1975) Atherosclerosis 22, 463-472

Twu, J.-S., Garfinkel, A. S. \& Schotz, M. C. (1976) Atherosclerosis 24, 119-128 